\title{
リコピン摂取時間帯がラットおよびヒトにおける 体内吸収に与える影響
}

\author{
青 木 雄 大 $^{1}$, 吉 田 和 敬 ${ }^{1}$, 信 田幸 ${ }^{*, 1}$, 砂 堀 諭, \\ 西田由 香, 加藤秀 夫 $^{2}$, 菅 沼 大 行 $^{1}$
}

(2017 年 1 月 5 日受付 ; 2017 年 4 月 3 日受理)

\begin{abstract}
要旨：リコピンはトマトに豊富に含まれるカロテノイドであり，強い抗酸化作用を有することが知られてい る。これまでに, 様々な栄養素の吸収に概日リズムが影響を与えることが示唆されてきているが, リコピン の吸収について，摂取時間带による影響を検証した報告はなされていない。そこで我々は，摂取時間带がリ コピンの吸収に与える影響を，ラットを用いた動物試験および健常な成人男女を対象としたヒト試験で検証 した。ラットおよびヒトに対し，リコピンを含む食品を，時間带を変えて摂取させ，血中リコピン濃度を測 定したところ, ラットでは活動期初期, ヒトでは朝に䎼取した際に血中リコピン濃度が最も上昇した。また, リコピンを撕取するまでの絶食時間が長くなるほど, 血中リコピン濃度の上昇が大きくなることが示された。 以上から，リコピンの吸収は絶食時間の長さの影響を受け，そのため朝に摂取した際に最も吸収率が高くな ることが推測された。
\end{abstract}

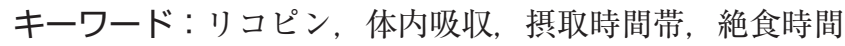

リコピンはトマトやトマト加工品に豊富に含まれるカ ロテノイドであり，活性酸素種，特に一重項酸素に対す る消去能が強いことが知られている ${ }^{12)}$ 。この抗酸化作 用を介して，リコピンは，がんや心血管疾患などの慢性 疾患のリスクを低下させると考えられている3゙。また近 年は, リコピンから生体内で生成されたリコピン代謝体 が種々の遺伝子の発現を調節することにより，抗酸化作 用や解毒作用などの生理作用を発現していることも明ら かになってきた ${ }^{4) 5}$ 。さらに疫学研究においても，血中 のリコピン濃度が高い人ほど，前立腺がんなどのがんや 心血管疾患といった慢性疾患のリスクが低くなることが 報告されておりり ${ }^{3(6-8)}$ ，リコピンを豊富に含むトマトなど の食品を積極的に摂取することは，生活習慣病の予防に 繋がることが期待される。

リコピンが生体内でその生理機能を発揮するために は，まず，生体内に吸収される必要がある。しかし，食 品からのリコピンの吸収率は様々な因子の影響を受ける ことが知られており，その吸収率を高めるためには「摂 り方」を工夫する必要がある9 。例えば，生のトマトを 摂取した場合よりも，トマトジュースやトマトペースト のような加工品を摂取した場合においてリコピンの吸収 率は高まることが報告されている ${ }^{10) 11}$ 。リコピンは，植
物体の中では細胞壁に守られた細胞内に色素体として存 在している。この細胞壁は，摂取した際にヒトの消化酵 素による分解を受けにくいが，加工によって細胞壁が壊 されることでリコピンが植物細胞から放出され，その吸 収率が高まると考えられている ${ }^{12)}$ 。また，リコピンは， 他の脂溶性の低分子物質と同様に, 小腸において胆汁酸 とともにミセルを形成し, 能動輸送㧍よび受動輸送に よって吸収されるため ${ }^{13)}$, ミセル化を促進するような摂 り方において，すなわち油と一緒に摂取したり，加熱な どにより立体異性体構造を変化（トランス体からシス体 に変化）させて摂取したりすることで吸収率が高まるこ とが知られている9 。

上述した「摃り方」はいずれも，リコピンを吸収され やすい状態にして腸管に届けるものであるが, リコピンを 吸収する側，すなわちヒトの側にも吸収率に影響を及ほ す因子が存在する。その一つが“概日リズム”である ${ }^{14)}$ リコピンと吸収経路が類似している脂質の吸収にも, 概 日リズムが影響していることが示唆されている。例えば, 小腸管腔側から小腸細胞内へのリコピンの能動輸送に関 与しているスカベンジャー受容体クラス B タイプ1（SR$\mathrm{B} 1)^{5) 1516)}$ や，小腸から肝臓への脂質の輸送に関与するミ クロソームトリグリセリド輸送タンパク質 (MTP), アポ

\footnotetext{
* 連絡者・別刷請求先（E-mail: Yukihiro_Nobuta@kagome.co.jp）

1 カゴメ株式会社イノベーション本部自然健康研究部（329-2762 栃木県那須塩原市西富山 17)

2 東北女子大学家政学部 (036-8530 青森県弘前市清原 1-1-16)

（旧所属：県立広島大学生命環境学部（734-8558 広島県広島市南区宇品東 1-1-71）
} 
リポタンパク質 A-IV (apoA-IV)，ノクターニンなどの発 現量はいずれも，概日リズムの影響を受けて日内変動す ることが知られている ${ }^{17-19)}$ 。また，これらの遺伝子の発現 量は, 給餌刺激により作り出された概日リズムの影響を 受けやすいとされている ${ }^{17-19)}$ 。これらの報告を踏まえると, リコピンの吸収率は，その摂取時間帯や，1日の中の給餌 （食事）のリズムの影響を受ける可能性がある。しかし， このことを検討した例は今までにない。

そこで本試験では, リコピンの摂取時間带がその吸収 率に与える影響を明らかにするため, リコピンの主要な 供給源であるトマトを試験食品とし, 摂取後のリコピン の血中濃度の推移を動物とヒトで評価するとともに, 動 物試験においては, 給飭刺激や SR-B1 遺伝子発現量と の関連について検討を行った。

\section{実 験 方 法}

\section{1. 動物 実 験}

1.1 実験動物および飼料 本研究においては, 実験 1 および実験 2 の 2 つの動物実験を実施したが，いずれも 「研究機関における動物実験等の実施に関する基本指針 (平成 18 年文部科学省告示第 71 号)」に基づき, 公立大 学法人県立広島大学動物実験委員会の許可を得た後に実 施した（許可番号：13HA003)。9 週齢の Wistar 系雄ラッ 卜（広島実験動物研究所）を購入し, 室温 $25 \pm 1^{\circ} \mathrm{C}$, 湿 度 $50 \pm 5 \%$ ，明暗逆転の明暗サイクル 12 時間（明期； 21:00-9:00, 暗期；9:00-21:00）の条件下で高床式ステ ンレスケージ（5匹/ケージ）に入れて飼育した。試験飼 料は, 通常飼料とトマト飼料（トマトペースト凍結乾燥 粉末を $10 \%$ 含有）の 2 種類とし, 飼料のエネルギー量, および，飼料全体のエネルギーに占めるタンパク質 $(\mathrm{P})$, 脂質 $(\mathrm{F})$, 炭水化物 (C) の比率 (PFC 比) が両飼料で ほほ同じになるよう, 表 1 に示した組成で調製した。卜 マト飼料中のリコピン濃度は, 実験 1 においては 6.5

表 1 試験飼料の栄養成分組成

\begin{tabular}{|c|c|c|}
\hline 成分 & \multicolumn{2}{|c|}{ 100g あたり } \\
\hline ミルクカゼイン（g) & 19.6 & 18.0 \\
\hline ラード（g) & 9.7 & 9.6 \\
\hline 大豆油（g） & 9.7 & 9.6 \\
\hline ショ糖（g） & 34.5 & 34.3 \\
\hline デキストリン（g) & 8.6 & 5.5 \\
\hline 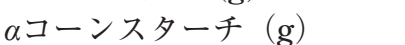 & 8.6 & 5.5 \\
\hline ミネラル配合（g） & 4.0 & 4.0 \\
\hline ビタミン配合（g） & 1.0 & 1.0 \\
\hline セルロース $(\mathrm{g})$ & 4.0 & 2.5 \\
\hline コレステロール（g） & 0.2 & 0.2 \\
\hline トマトペースト凍結乾燥粉末 $(g)$ & 0.0 & 10.0 \\
\hline エネルギー（kcal） & 460.4 & 457.1 \\
\hline$P: F: C$ & $17: 38: 45$ & $17: 38: 45$ \\
\hline
\end{tabular}

$\mathrm{mg} / 100 \mathrm{~g}$, 実験 2 においては, $9.8 \mathrm{mg} / 100 \mathrm{~g}$ であった。

1.2 摂餌方法 実験 1 では, 75 匹のラットを 25 匹 ずつ, Breakfast (B) 群, Lunch (L) 群, Dinner (D) 群の 3 群に分けた。各群のラットとも, 暗期（9:00-21： 00）の間に, 初期 (9:00-11:00), 中期 (13:00-15: 00), 終期（17:00-19:00）の 3 回に分けて通常飼料を摂 取させ， 1 週間馴化させた。馴化後， 3 回の摂飭タイミ ングのうち, $\mathrm{B}$ 群は暗期の初期, $\mathrm{L}$ 群は暗期の中期, $\mathrm{D}$ 群は暗期の終期に，それぞれトマト飼料を撖取させ，他 の摂餌タイミングにおいては, 通常飼料を摂取させた(図 1A)。各群, 各摂餌夕イミングとも, 給餌量を 1 ケージ (5 匹）あたり $30 \mathrm{~g}$ に統一して完食させ, 摂餌期間は 4 週 間とした。実験 2 では, 75 匹のラットを 25 匹ずつ, Breakfast（B) 群, Late Breakfast（LB） 群, Late Dinner（LD）群の 3 群に分けた。B 群の䀧餌タイミングは 実験 1 と同様とした。LB 群は, 全ての摂慨時間帯を B 群から 4 時間後ろにずらした。LD群は, 3 回目の摂餌 時間带のみを B 群から 4 時間後ろにずらした（図 1B）。 そのため, $\mathrm{LB}$ 群と $\mathrm{LD}$ 群の 3 回目の摂飭時間带は明期 であったが, 3 回目の摂䬣量は全群間で差がなかった。 それぞれの摂慨タイミングで通常飼料を 1 週間摂取させ 馴化後, 図1B に示したタイミングで, トマト飼料扔よ び通常飼料を摂取させた。摄餌量, 摂餌期間は実験 1 と 同様とした。

1.3 血液および小腸上皮の採取 4 週間の摂慨期間の 最終日の 8:00, 12:00, 16:00, 20:00, 24:00 の各時刻に, 各群 5 匹ずつ, チオペンタール麻酔下で, 実験 1 では肝 静脈から, 実験 2 では心臓から, いずれも全血を採取し, 採取後に頸椎脱臼により安楽死させた。採取した血液は, $1,000 \times g, 10$ 分, $4^{\circ} \mathrm{C}$ で遠心分離後, 上清を回収し血清 試料とした。実験 2 では, 遺伝子発現解析を目的に小腸 上皮を採取した。ラットの空腸上部位を約 $2 \mathrm{~cm}$ 切り出し, 内腔に生理食塩水を通して洗浄後, 腸を切開した。カバー

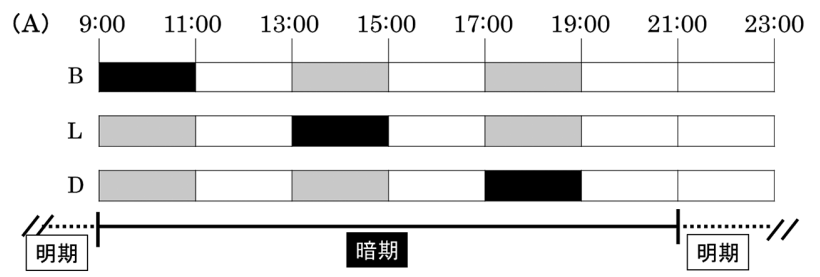

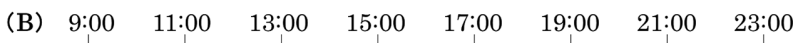

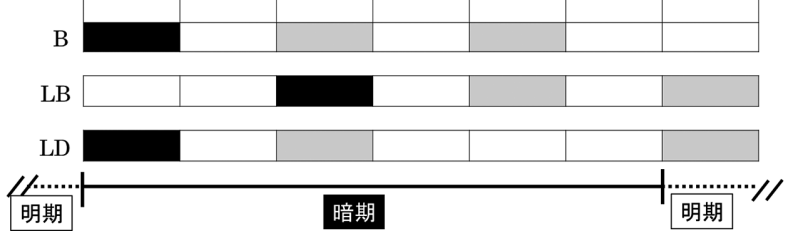

図 1 摂慨スケジュール

（A）に実験 1，（B）に実験 2 の摂餌スケジュールを示し た。各試験群には, 図中の口 (黒色) で示した時間带に トマト飼料を, (灰色) で示した時間带に通常飼料を 摂取させた。また，暗期を実線で，明期を点線で示した。 
ガラスを用いて小腸粘膜を採取し， $2 \mathrm{~mL}$ の TRIzol（サー モフィッシャーサイエンティフィック(株), 神奈川) に 懸濁し, RNA 抽出まで $-80^{\circ} \mathrm{C}$ で保存した。

1.4 血清リコピン濃度の測定 血清リコピン濃度は,

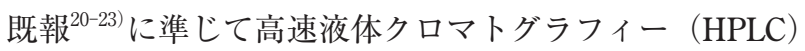
により定量した。血清 $200 \mu \mathrm{L}$ に, 内部標準物質である トランス- $\beta-8$-アア゚カロテナールのエタノール溶液 $(10$ $\mu \mathrm{M} ）$ を $10 \mu \mathrm{L}$ 添加した。続いて， $0.01 \% （ \mathrm{w} / \mathrm{v} ）$ のブチ ルヒドロキシルトルエン含有エタノールを $1 \mathrm{~mL}$ 添加 し,さらに, ヘキサンとジクロロメタンの混合溶媒 (4: 1）（v/v）を $4 \mathrm{~mL}$ 加えた。混合溶液をラボミキサーに て 1 分間攪汼した後, $1,000 \times g, 4{ }^{\circ} \mathrm{C} て ゙ 10$ 分間遠心分離 し, 上清を回収した。この抽出操作をもう 1 度繰り返し, 上清を合せ，溶媒を窒素ガスで留去した。0.2 mLのへ キサン：アセトン：エタノール：トルエン (10:7:6:7) $(\mathrm{v} / \mathrm{v} / \mathrm{v} / \mathrm{v})$ 溶液に残椬を溶解させ， $0.20 \mu \mathrm{m}$ フィルター でろ過し, HPLC 用試料とした。HPLCによる分析には, C30 カロテノイドカラム $(250 \times 4.6 \mathrm{~mm}, 5 \mu \mathrm{m}, \quad$ (株) ワ イエムシィ, 京都) と PDA 検出器 (SPD-M10, (株) 島 津製作所, 京都) を用い, $460 \mathrm{~nm}$ における吸光度を測 定した。移動相 A（A 液）はメタノール：tert-ブチルメ チルエーテル : 水 $(75: 5: 20)(\mathrm{v} / \mathrm{v} / \mathrm{v})$ とし, 移動相 B $(\mathrm{B}$ 液) はメタノール：tert-ブチルメチルエーテル：水（8： 90:2）（v/v/v）とした。グラジエント条件は，100\% A 液 (0 分) $\rightarrow 100 \%$ B 液 $(25$ 分) $\rightarrow 100 \%$ B 液 $(28$ 分) $\rightarrow 100 \% \mathrm{~A}$ 液（30 分） $\rightarrow 100 \% \mathrm{~A}$ 液（40 分）のリニアグ ラジェントとし, 流速は毎分 $0.2 \mathrm{~mL}$ とした。測定值は, トランス- $\beta-8$-アポカロテナールの抽出効率で補正した。

1.5 小腸の遺伝子発現解析 小腸粘膜の TRIzol 懸濁 液 $1 \mathrm{~mL}$ に, $200 \mu \mathrm{L}$ のクロロホルムを加えて攪拌後, 室 温で 2 分間静置し, $12,000 \times g, 15$ 分間, $4{ }^{\circ} \mathrm{C}$ で遠心分離 した。遠心分離した上清のうち $350 \mu \mathrm{L}$ から, MagNA Pure Compact（ロシュ・ダイアグノスティックス(株), 東京）により RNAを抽出し, cDNA 合成までー $80^{\circ} \mathrm{C} て ゙$ 保存した。RNAから cDNAへの逆転写反応には, PrimeScript ${ }^{\circledR}$ RT Master Mix (Perfect Real Time) (タカラバイ オ(株), 滋賀)を用いた。mRNA発現量の定量は, SYBR Premix Ex Taq II（タカラバイオ(株)）と ABI PRISM 7900 Sequence Detection System（サーモフィッ シャーサイエンティフィック(株)）を用いたRT-PCR 反 応により行った。反応条件は, 初期変性 $\left(95^{\circ} \mathrm{C}, 30\right.$ 秒 $)$ $\rightarrow \mathrm{PCR}$ (変性 : $95^{\circ} \mathrm{C}, 5$ 秒 $\rightarrow$ アニーリング/伸長 : $60^{\circ} \mathrm{C}$, 30 秒 $) \times 40$ サイクル $\rightarrow$ 解離 $\left(95^{\circ} \mathrm{C}, 15\right.$ 秒 $\rightarrow 60^{\circ} \mathrm{C}, 60$ 秒 $\rightarrow 95^{\circ} \mathrm{C}, 15$ 秒) とした。プライマーは, タカラバイオ(株) より定量 RT-PCR 用のプライマーを購入した（表 2)。 SR-B1 mRNA の発現量は, ハウスキーピング遺伝子であ る $\beta$-アクチンの発現量に対する相対值で示した。

1.6 結果の解析 データは平均值土標準偏差で示し た。3 群間の比較には, 一元配置分散分析を使用した。 post-hoc test には, 実験 1 においてはTurkey 多重比較 検定を, 実験 2 においては, B 群を対照群としたDunnett 検定を用いた。2 群間の比較には, 対応のない $t$ 検 定を用いた。いずれの検定でも， $p<0.05$ の場合に有意 差ありとした。統計解析ソフトには $\mathrm{EZR}^{24)}($ ver. 1.26) を 用いた。

\section{2. ヒトを対象とした試験}

2.1 研究対象者 試験開始時の研究対象者数の目標 を 24 名に設定し, 50 名以上の 20 歳以上 55 歳以下の健 常な成人男女に対し, 口頭および書面にて試験内容を説 明した後, 書面による参加同意を得られた者を研究対象 者候補とした。なお，以下の a) h）の除外基準に該当 する者は候補から除外した。a）試験責任医師に血中中 性脂肪が高いと判断された者，b）肝機能に異常が見ら れた者, c）消化吸収, 呼吸器に障害がある者, d） 1 日 3 食（朝・昼・晚）の食事習慣を持たない者，e）授乳， 妊娠中の者，f）試験食品にアレルギーがある者，g）契 煙習慣がある者, h）他のヒトを対象とする試験に参加 している者。さらに, 研究対象者候補を対象に, 試験開 始前にリコピンの吸収量に関する調査を実施し, リコピ ンを $16 \mathrm{mg}$ 含む食塩無添加のトマトジュース $160 \mathrm{~mL}$ 摂取した 6 時間後の血清リコピン濃度の変化量が 0.025 $\mu \mathrm{M}$ 以上であった者を選定し, 研究対象者とした。

2.2 倫理審査 研究対象者の健康管理および採血は, チョダパラメディカルケアクリニック（東京都千代田区 内神田 3-3-5）に委託した。研究計画は, カゴメ株式会 社研究倫理審査委員会（審査番号：2015-R08）およびチ ヨダパラメディカルケアクリニック臨床試験審査委員会 （KGM2015C03）にて審査され，承認を得た。研究計画 の立案, 実施にあたっては, ヘルシンキ宣言および人を 対象とする医学系研究に関する倫理指針を遵守した。

2.3 試験デザインと介入方法 試験デザインは非盲 検試験とした。試験食品には, リコピンを $16 \mathrm{mg}$ 含む 食塩無添加のトマトジュース $160 \mathrm{~mL}$ を用いた。研究対 象者には, 1 日に 1 回, 8:00 (朝摂取), 12:00 (昼摂取), 18:00 (夜摂取) のいずれかの時間帯で試験食品を摂取 してもらった。朝摂取時は, 前日の夕食を 21:00 までに,

表 2 PCR プライマーの配列

\begin{tabular}{|c|c|c|c|}
\hline \multirow[t]{2}{*}{ NM_031144 } & Actb & Forward & GGAGATTACTGCCCTGGCTCCTA \\
\hline & & Reverse & GACTCATCGTACTCCTGCTTGCTG \\
\hline \multirow[t]{2}{*}{ NM_031541 } & Scarb1 & Forward & TTCATGAACCCGTGGACCAA \\
\hline & & Reverse & CCCTGGAATGCCTGGAACA \\
\hline
\end{tabular}

$A c t b, \beta$-アクチン; Scarb 1, スカベンジャー受容体クラス B タイプ 1 (SR-B1). 
昼摂取時は当日の朝食を 8:00 までに, 夜摂取時は当日 の昼食を $14: 00$ までに摂るよう指導し, 試験食品摂取 時は, 試験食品以外の飲食を禁止した。各試験食品の摂 取には, 1 週間の間隔を設けた。試験デザインを図 2 に 示した。試験期間中, 研究対象者には制限事項として,

a）試験開始前からの生活習慣を変えないこと, b）過度 の運動，節食，過食をしないこと，c）カロテノイドを 含むサプリメント, 野菜ジュース, 野菜・果実ミックス ジュース，特にリコピンを多く含む野菜果実やその加工 食品を撖取しないことを遵守するよう指導した。また, 研究対象者には, 体調, 食事摂取時間, 服用した医薬品 を試験期間中毎日，日誌に記入してもらった。研究対象 者のうち, 試験を全て終了し, 試験期間中の制限事項を 遵守していた者を解析対象者として結果を解析した。

2.4 吸収されたリコピン濃度の測定 研究対象者か ら, 試験食品摂取 30 分前, 2 時間後, 4 時間後, 6 時間後,

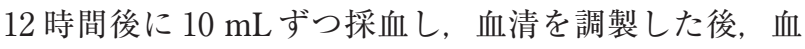
清中の triglyceride-rich lipoprotein（TRL）画分中に含ま れるリコピン濃度を測定した。血清 $800 \mu \mathrm{L}$ の上に超純 水 $800 \mu \mathrm{L}$ を重層し, $20^{\circ} \mathrm{C}, 26,000 \times g$ で 4 時間遠心分離 した。遠心後の血清の底面より $800 \mu \mathrm{L}$ を採取し, 残っ た上層部をTRL 画分とした。TRL画分中のリコピン濃 度の測定は, 回収した TRL 画分 $800 \mu \mathrm{L}$ 用いて, 1.4 の方法と同様に実施した。

2.5 有害事象の収集 試験期間中に発生した有害事 象の収集と, 発生した有害事象と試験食品摂取との関連 性を検証するために, 試験食品摂取前の採血時に医師の 問診を行い, 研究対象者の体調を確認した。また, 試験 食品摂取 12 時間後に採取した血液を用いて, 血液学検 查, 血液生化学検查を実施し, 試験責任医師が, 有害事 象の発生と検查值の異常変動の有無を確認し, 有害事象 や異常変動が認められた場合は, 試験食品摂取との関連 を判断した。

2.6 結果の解析方法 結果は平均值士標準偏差で示 した。試験食品摂取前と摂取後の各時間での TRL 画分 中のリコピン濃度から, TRL 画分中のリコピン濃度変化
量（ムリコピン濃度）を算出した。また, 試験食品摂取 前から摂取後 12 時間までの TRL 画分中リコピン濃度の 応答濃度曲線下面積 $\left(\mathrm{IAUC}_{0-12 \mathrm{~h}}\right)$ を算出した。それぞれ の値について, Two-way ANOVAを実施後, 朝摂取時の 值を対照として post-hocで Dunnett検定を用い, 統計 解析を実施した。全ての摂取時間帯において, 日誌に記 載された食事時間と試験食品の摂取時間とから, 試験食 品摂取までの絶食時間を算出し, 絶食時間と $\mathrm{IAUC}_{0-12 \mathrm{~h}}$ との関連性を Pearsonの積率相関係数により求めた。ま た, 統計解析前にスミルノフ・グラブス検定により外れ 值の検定を実施した。いずれの検定でも， $p<0.05$ の場 合に有意差ありとした。統計解析ソフトは, Dunnett 検 定に SPSS（ver. 15.0）を用い, スミルノフ・グラブス検 定に $\mathrm{EZR}^{24)}$ (ver. 1.26）を用いた。

\section{実 験 結 果}

\section{1. 動物 試 験}

1.1 血清リコピン濃度の推移 実験 1 に抢ける各群 の血清リコピン濃度の推移を図 3 に示した。トマト飼料 摂取の 3 時間後において, B 群の血清リコピン濃度が他 の 2 群と比較して有意に高值を示した。他の時間带にお いては, 血清リコピン濃度に群間で有意差は確認されな かった。本試験は同一の個体から経時的に採血を行った ものではないが, 各群の血清リコピン濃度の平均值の推 移から血中濃度曲線下面積 (AUC) を算出 (23 時間値は, -1 時間值と同じと仮定）したところ，B 群において最 も高い値となった（B 群：0.466, L 群 : 0.348, D 群： 0.319 ; 単位 $: \mu \mathrm{g} / \mathrm{mL} \times \mathrm{hr}$, 図は示していない)。

実験 2 における各群の血清リコピン濃度の推移を図 4 に示した。トマト飼料の摂取 15 時間後において, LD 群の血清リコピン濃度が B 群と比較して有意に低值で あった。それ以外の時間帯においては, 血清リコピン濃 度に群間差は見られなかった。実験 1 と同様にAUCを 算出したところ, B 群において最も高い值となり, 次い で LB 群, LD 群の順となった (B 群：0.415, LB 群：0.342, $\mathrm{LD}$ 群 : 0.280 ; 単位 : $\mu \mathrm{g} / \mathrm{mL} \times \mathrm{hr}$, 図は示していない)。

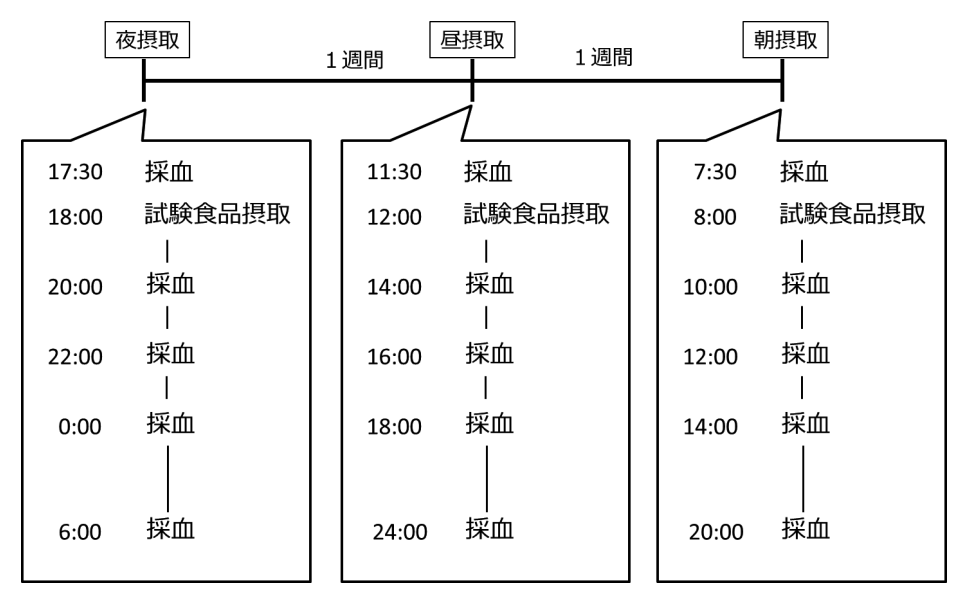

図 2

ヒト試験のスケジュール 


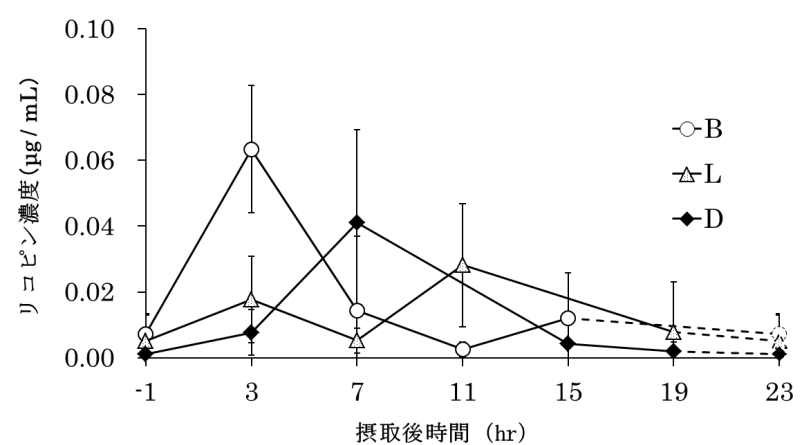

図 3 実験 1 における各群の血清リコピン濃度の推移 トマト飼料摂取開始時刻（B 群 : 9:00, L 群 : 13:00, D 群：17:00）を 0 時間とし, 各群の血清リコピン濃度を 経時的に示した。なお， 23 時間の值は -1 時間の值と同 じ值と仮定し, 点線で示した。 $n=3-5$, 平均值 \pm 標準 偏差。異符号間に有意差あり $(p<0.05)$ 。

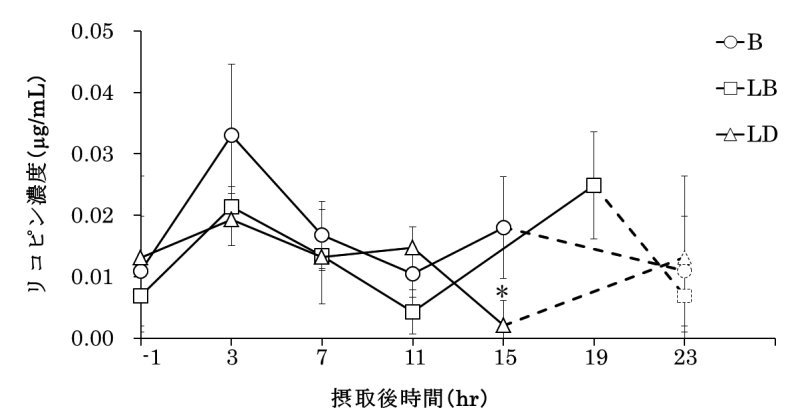

図 4 実験 2 における各群の血清リコピン濃度の推移 トマト飼料摂取開始時刻（B 群, LD 群 : 9:00, LB 群 : 13:00）を0 時間とし, 各群の血清リコピン濃度を経時 的に示した。なお， 23 時間の值は -1 時間の值と同じ值 と仮定し, 点線で示した。 $n=5$, 平均值士標準偏差。 * $p<0.05$ (vs. B 群)。

1.2 小腸の SR-B1 mRNA 発現量 実験 2 における小 腸の SR-B1 mRNA 発現量の推移を図 5 に示した。いず れの時間帯においても，群間で SR-B1 mRNA 発現量に 有意な差はなかった。

\section{2. ヒトを対象とした試験}

2.1 解析対象者の選定 文書による同意を得た 54 名 の候補者のうち，いずれの除外基準にも該当せず，トマ トジュース $160 \mathrm{~mL}$ （リコピン $16 \mathrm{mg}$ ）を摂取した 6 時 間後の血清中のリコピン濃度の変化量が $0.025 \mu \mathrm{M}$ 以上 であった 23 名を研究対象者として選定した。試験期間 中に脱落, 中止例はなく, 試験期間中の制限事項からの 逸脱も認められなかったため, 研究対象者 23 名全てを 解析対象者とした。解析対象者の背景は, 男性 12 名, 女性 11 名, 平均年齢は $40.1 \pm 7.7$ 歳であった。その後, スミルノフ・グラブス検定により外れ值と判断された 3 名を除き, 20 名で以降の解析を実施した。

2.2 各摂取時間帯における TRL 画分のリコピン濃度 変化およびその $\mathrm{IAUC}_{0-12 \mathrm{~h}}$ 試験食品摂取による TRL 画 分のリコピン濃度の変化を, ムリコピン濃度の推移（図 6) と $\mathrm{IAUC}_{0-12 \mathrm{~h}}$ (図 7) として示した。TRL画分の

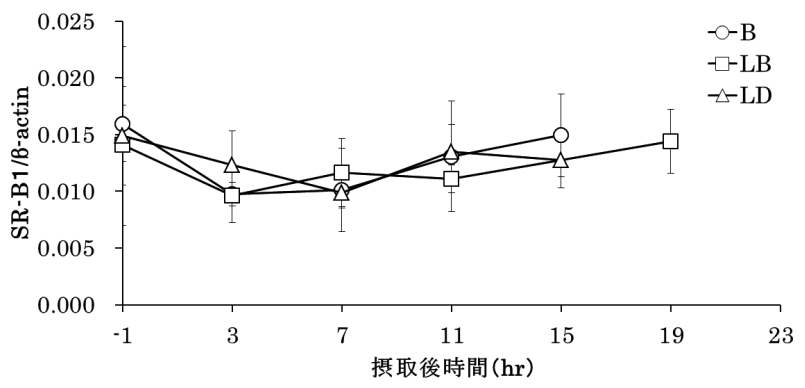

図 5 実験 2 における各群の小腸 SR-B1 mRNA 発現量 の推移

トマト飼料摂取開始時刻（B 群, LD 群 : 9:00, LB 群 : 13:00）を 0 時間とし, SR-B1 mRNA発現量を, $\beta$-actin 発現量に対する相対量として経時的に示した。 $n=5$, 平均値 \pm 標準偏差。

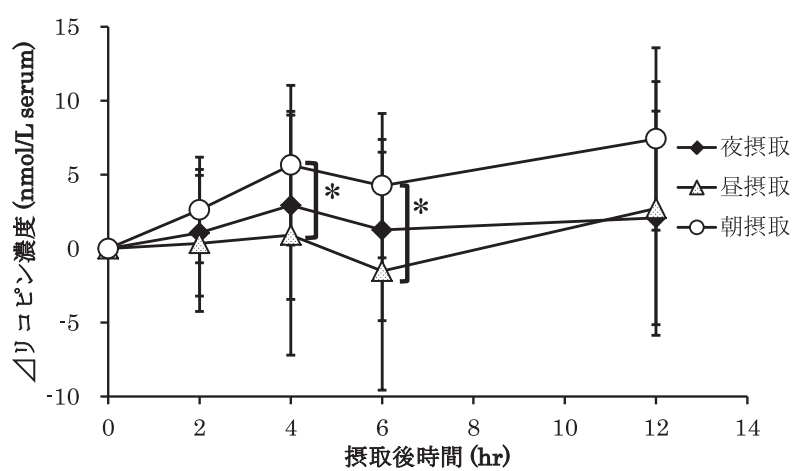

図 6 ヒト試験における TRL 画分中のリコピン濃度変 化量の推移

トマトジュース摂取時刻（朝摂取：8:00, 昼摂取 : 12 : 00, 夜摂取：18:00）を0 時間とし, その時点からの TRL 画分中のリコピン濃度の変化量を経時的に示した。 $n=20$, 平均值 \pm 標準偏差。 ${ }^{*} p<0.05$ (vs. 朝摂取)。

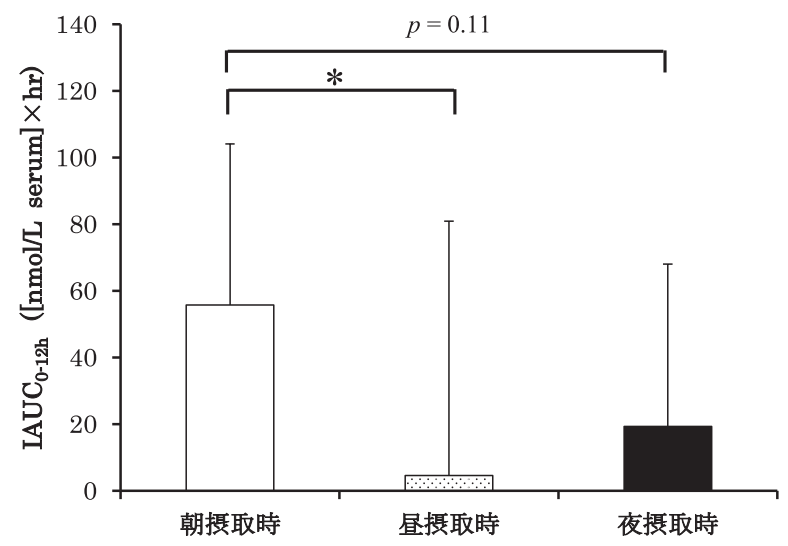

図 7 ヒト試験における TRL画分中リコピン濃度の $\mathrm{IAUC}_{0-12 \mathrm{~h}}$

試験食品摂取から 12 時間後までの TRL 画分中のリコピ ン濃度変化量から $\mathrm{IAUC}_{0-12 \mathrm{~h}}$ を算出した。 $n=20$, 平均 值 + 標準偏差。 ${ }^{*} p<0.05$ (vs. 朝摂取)。

ン濃度は，試験食品摂取後 4 時間および 6 時間において, 昼摂取時よりも朝摂取時で有意に高值を示した。また, $\mathrm{IAUC}_{0-12 \mathrm{~h}}$ も, 昼摂取時と比較して, 朝摂取時では有意に 高值であった。なお, 夜摂取時との比較でも, 朝摂取時 
表 3 絶食時間と TRL 画分中の $\mathrm{IAUC}_{0-12 \mathrm{~h}}$

\begin{tabular}{ccc}
\hline \hline & $\begin{array}{c}\text { 絶食時間 } \\
\text { (時間 })\end{array}$ & $\begin{array}{c}\text { IAUC }_{0-12 \mathrm{~h}} \\
(\mu \mathrm{mol} / \mathrm{L} \text { serum })\end{array}$ \\
\hline 朝摂取時 & $12.0 \pm 0.5$ & $55.8 \pm 49.4$ \\
昼撖取時 & $4.4 \pm 0.4$ & $4.6 \pm 76.3$ \\
夜摂取時 & $5.0 \pm 0.6$ & $19.3 \pm 48.7$ \\
\hline \hline
\end{tabular}

は高值を示したが, 統計学的有意差は認められなかった。

2.3 絶食時間と $\mathrm{IAUC}_{0-12 \mathrm{~h}}$ との関連性 試験食品摂取 前の絶食時間と $\mathrm{IAUC}_{0-12 \mathrm{~h}}$ を, 摂取時間帯ごとに表 3 に示 した。平均絶食時間は朝, 夜, 昼の順に長く, $\mathrm{IAUC}_{0-12 \mathrm{~h}}$ の值もまた朝，夜，昼の順に大きかった。全摂取時間帯 の絶食時間と $\mathrm{IAUC}_{0-12 \mathrm{~h}}$ との関連性を Pearsonの積率相 関係数により求めた結果, 絶食時間と $\mathrm{IAUC}_{0-12 \mathrm{~h}}$ の值との 間には正の相関があることが示された（相関係数：0.357, $p<0.01$ )。

2.4 有害事象 試験期間中, 研究対象者のうち, 1 名の血中尿酸值が高值になる, 2 名の中性脂肪が高值に なる，1名が頭痛を発症するといった有害事象が発生し たが, その全てについて, 試験食品摂取との因果関係は ないと試験責任医師により判断され, 試験食品摂取との 関連性が否定できない有害事象は認められなかった。

\section{考察}

摂取時間帯の違いがリコピンの吸収率に与える影響を 明らかにするために，動物試験（実験 1）とヒト試験を 実施した。また，そこで得られた結果のメカニズムを明 らかにするために，給餌刺激がリコピンの吸収率や SR-B1 の遺伝子発現量に与える影響を検証する動物試験 （実験 2) を実施した。食品成分の摂取時間帯とその吸 収率との関連を検証する上では，一定の食事リズムを形 成している条件下で試験を実施することが重要である。 そこで, 動物試験においては, いずれの実験でも, ヒト の食事様式 (1 日 3 食) を模すために, ヒトにとっての朝, 昼, 夜にあたる活動期初期, 中期, 後期でそれぞれ時間 を決めて給慨して馴化し，ヒト試験においては，1日3 食を規則正しく摂取している者を研究対象者とした。

なお，今回測定した体内へのリコピン吸収量は，動物 試験，およびヒト試験ともに比較的大きなバラつきが認 められた。この要因として, 動物試験では, ラットを 5 匹/ケージで飼育したことにより個体ごとに摂餌量のバ ラつきが生じたこと, ヒト試験では, 体内のリコピン蓄 積量に差異があったことなどが考えられる。しかし, 放 射性同位体で標識したリコピンを用いて，その体内吸収

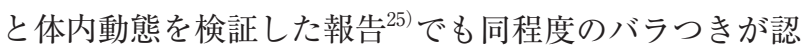
められていることから, 本試験の結果におけるリコピン 吸収量のバラつきは妥当な範囲内であり, 結果を考察す るにあたって問題ないものと考える。一方, これらのバ ラつきを抑制する手段としては, 動物の個別飼育を行い,
摂餌量の個体差をなくすことや, ヒト試験の対象者選定 において，普段の食事でリコピンの摂取量が低いヒトを 対象とすることなどが考えられる。但し, 前者は個別で 飼育することによる動物へのストレスが懸念されたこ と, 後者は, 研究対象者選抜において, トマトジュース 飲用時に一定幅以上の血清リコピン濃度の上昇が認めら れた者のみを採用したことから, 本研究においては実施 しなかった。

実験 1 の結果, 血清中リコピン濃度の AUC は活動期 初期にトマト飼料を摂取した B 群が最も高く, L 群と D 群では同等の值を示した。また, ヒトに対し, 朝, 昼, 夜のそれぞれの時間帯にリコピンを $16 \mathrm{mg}$ 含むトマト ジュースを摂取させたところ, $\mathrm{IAUC}_{0-12 \mathrm{~h}}$ は朝摂取時で 最も高く, 昼摂取時との比較では, その差は統計的に有 意であった。この結果は, 同じ量のリコピンを摂取する 場合, 朝 (活動初期) に摂取すると, 昼や夜に摂取した 時と比べて, リコピンの体内への吸収率が高まる可能性 があることを示すものであると考えられる。一方で, こ の結果がリコピンの吸収ではなく, 消化・吸収過程にお けるリコピンの代謝の日内変動により引き起こされた, すなわち, 朝は代謝されにくく, 昼や夜ではリコピンの 代謝が活発に行われていた可能性もある。そこで, 本試 験の結果が, リコピンの吸収の違いにより引き起こされ たのか, それとも代謝の違いにより引き起こされたのか を考察した。

リコピンは, 主に腸管や肝臓に偏在する $\beta$-Carotene-9', 10 oxygenase（BCO2）により代謝される。BCO2によりリコ ピンが代謝されると, 代謝産物として Apo-10'lycopenal が 産生されることが明らかになっている ${ }^{26) 27)}$ 。既報を調査した 結果, BCO2 の発現や活性に関する日内変動を検証した報 告は認められなかった。そこで, 本試験で分析した血液サ ンプル中に含まれる Apo-10-1ycopenal 量を確認したが, い ずれの血液サンプルでも, その量は検出限界以下であった。 また, 実験 1 では, 各群で血清中リコピン濃度が最大值と なる時間が異なっており, 代謝がこれに影響を与えた可能 性が考えられた。しかし, ラットにおけるリコピンの体内動 態を検証した報告では, リコピンの肝蔵中濃度は, 経口摂 取後飽和するまでに 24 時間程度かかるとされており ${ }^{28)}$, 本 試験で検出された動物試験における血清中リコピン濃度が 最大值となる時間よりも後に生じている。さらに, ヒトにお いても, 血中リコピン濃度の半減期は, 5 日間から 33 日間 と幅はあるものの, 比較的長期である ${ }^{20) 29) 30) 。 こ の こ と か ら, ~}$ 今回測定した血中リコピン濃度の值に対し, リコピンの代 謝が与えた影響は低く, リコピンの吸収の違いが与えた影 響が大きいと判断した。

次に, 本試験で得られた吸収率の差が, 1 日の時間带 の中で「朝」という時間帯に摂取したことによるものな のか, もしくは, 別の要因によるものなのかを考察した。 実験 2 において, 最後（ヒトの夜に該当）の給䬶時間を 4 時間遅らせた LD 群では, B 群ないしは LB 群と比較 
して絶食時間が短く（10 時間 vs. 14 時間），血清中リコ ピン濃度の AUC は低值を示した。また, 最後の給餌時 間は同じだが，14時間絶食し，ヒトの昼に該当する時 間帯にリコピン慨を摂取した LB 群と比較しても，LD 群の血清中リコピン濃度の AUC は低值を示した。この ことから, 朝摂取時にリコピンの吸収率が高くなった原 因は,「朝」という時間带よりも, 絶食時間の長さに強 く影響を受ける可能性が高いと考えられた。またこのこ とは, ヒト試験において, 試験食品摂取時までの絶食時 間と $\mathrm{IAUC}_{0-12 \mathrm{~h}}$ との関連性を解析した結果，両者の間に 正の相関が確認され, 試験食品捸取までの絶食時間が長 い程, $\mathrm{IAUC}_{0-12 \mathrm{~h}}$ が高かったことからも支持される。こ れらのことから, 絶食時間が長いほどリコピンの吸収率 が高くなることが推測された。

前述した通り，リコピンは胆汁酸とともにミセルを形 成した後, 能動輸送と受動輸送とで体内に吸収される。 このうち, リコピンの能動輸送に関与する SR-B1の発 現リズムは，給餌刺激の影響を受けることが知られてい

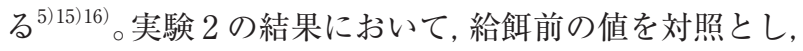
その他の各時間における SR-B1 mRNAの発現量を Dunnettの多重比較検定で統計解析した結果, B 群, LB 群 においては, 給餌直前の発現量が給餌直後の発現量より も高い傾向が見られた（それぞれ $p=0.07, p=0.09 ） 。$ 従って, 既報 ${ }^{31}{ }^{32)}$ の通り SR-B1 の発現リズムは, 給餌刺 激の影響を, ある程度受けることが示唆された。しかし, 各群の小腸の SR-B1 mRNAの発現量は, 測定したいず れの時間でも群間差はなく, SR-B1 mRNAの発現量は, 絶食時間の長さの影響を受けていないことが示唆され た。したがって，絶食時間が長くなることによるリコピ ン吸収率の増加は, SR-B1 を介した能動輸送の促進によ るものではないと考えられた。一方，胆汁酸は食事をす ることで濃度が高くなるが，ヒトにおいては食後 4 時間 で食事前の胆汁酸濃度に戻ることが知られている ${ }^{33)}$ 。今 回実施したヒト試験では, 朝, 昼, 夜いずれの摂取時間 帯においても 4 時間以上の絶食を課しており, 研究対象 者間で胆汁酸濃度には差がなかったと考えられる。その ため, 本試験で得られた絶食時間の長さとリコピンの吸 収率との関係が, 胆汁酸濃度の違いの影響を受けていた 可能性は低いと推測された。以上から，これまで一般的 に知られているリコピンの吸収メカニズムからでは, 絶 食時間の長さとリコピンの吸収との関連を考察すること ができなかったため, 絶食によって生体に生じる変化を 中心に，本試験の結果に対する考察を実施した。

絶食による生体内の変化の中で物質の吸収に影響を与 えることが知られている要素として, 胃内 $\mathrm{pH}$ と胃内容 物排出速度 (gastric emptying rate, GER) がある。消 化管の $\mathrm{pH}$ が異なることで, 体内への吸収性が変化する 物質があることが知られている ${ }^{34)}$ 。すなわち, 絶食や摂 食により胃の $\mathrm{pH}$ が変化し, 吸収率に影響を与えた可能 性が考えられるが, 胃の $\mathrm{pH}$ は食後 2-3 時間で空腹時と
同じ状態に戻ることが知られている。今回のヒト試験で は, 試験食品摂取までの絶食時間が最低でも 4 時間以上 であるため, 各摂取時間帯での胃の $\mathrm{pH}$ に大きな違いは なかったと考えられる。GERは, 食物が胃に滞留して いる場合遅くなり, 食物がない場合は速くなることが知 られている ${ }^{35)}$ 。GERが遅くなると, 経口摂取した物質 が腸管に到達する時間が遅くなるため, 体内への吸収速 度が遅くなると共に, 体内における最大濃度も低くなる。 一般的に, ラットやヒトの食物の胃滞留時間は 3 時間程 度と言われているが, 実験 1 の L 群や D 群は, 通常飼 料を捸取した 2 時間後にトマト飼料を捸取していたた め, トマト飼料摂取時には食物が胃内に滞留していた可 能性が高い。実験 1 の L 群や D 群では, B 群と比較して, リコピンの血清中の最大濃度が低くなっており，かつ, 最大濃度を検出した時間も遅くなっていたことから，リ コピンの吸収が GERにより影響を受けた可能性がある と考えられた。一方で, 実験 2 の LD 群においては, 通 常飼料摂取の 10 時間後にトマト飼料を摂取しており, 食物の胃内滞留がほとんどないと考えられる状況である にもかかわらず，B 群と比較してリコピン吸収率が低く なった。加えて, ヒト試験では, 食事の間隔を最低でも 4 時間空けているため, 試験食品摂取時の GERが, 前 の食事の胃内滞留の影響を受けていた可能性は低いと考 えられた。以上より, 実験 1 の結果からは, GERの関 与を否定できないが, 実験 2 やヒト試験結果を踏まえる と, GERの関与は低いと考えられた。そのため, 本試 験の結果と, 既報の情報だけでは, 絶食時間の長さによ るリコピンの吸収率向上の要因を特定するには至らな かった。

これまで,リコピンの吸収量を高める摂取方法として, 一緒に摂取する食品の成分, 加工方法, リコピンの立体 構造などに注目して研究がなされてきたが, 本試験にお いては，摂取時間带による吸収率の違いを検証した。そ の結果, 活動期初期や朝にリコピンを摂取することで, 吸収率が高くなること，そして，この結果には絶食時間 の長さが関連していると考えられることを明らかにし た。この結果を受け, 我々は, 本試験で対象としたリコ ピン以外の栄養素について, 摂取時間帯や絶食時間が吸 収量に与える影響について検討した報告例を調査した が，調査した範囲では，絶食時間の長さが吸収に影響を 与えることを示した報告は認められなかった。栄養素に より吸収のメカニズムは異なることから, 各栄養素の最 適な吸収時間帯や, 絶食時間の長さが吸収に与えるか否 かについては個々に検討を要すると考える。また, 本試 験でリコピンの吸収と絶食時間との関連があった要因 は, 今回の研究だけでは明確にすることができなかった。 この要因を明らかにするためには, 今後, 消化管におけ るリコピンの吸収メカニズムの詳細を明らかにすると共 に，それにかかわる因子が絶食時間によってどのような 影響を受けるのかを明らかにする必要がある。 


\section{文献}

1) Di Mascio P, Kaiser S, Sies H (1989) Lycopene as the most efficient biological carotenoid singlet oxygen quencher. Arch Biochem Biophys 274: 532-8.

2) Sies H, Stahl W (1995) Vitamins E and C, beta-carotene, and other carotenoids as antioxidants. Am J Clin Nutr 62: 1315-21.

3) Agarwal S, Rao AV (2000) Tomato lycopene and its role in human health and chronic diseases. CMAJ 163: 739-44.

4) Erdman JW Jr, Ford NA, Lindshield BL (2009) Are the health attributes of lycopene related to its antioxidant function? Arch Biochem Biophys 483: 229-35.

5) Wang XD (2012) Lycopene metabolism and its biological significance. Am J Clin Nutr 96: 1214S-22S.

6) Jain MG, Hislop GT, Howe GR, Ghadirian P (1999) Plant foods, antioxidants, and prostate cancer risk: findings from case-control studies in Canada. Nutr Cancer 34: 173-84.

7) Arab L, Steck S (2000) Lycopene and cardiovascular disease. Am J Clin Nutr 71: 1691S-7S.

8) Giovannucci E, Rimm EB, Liu Y, Stampfer MJ, Willett WC (2002) A prospective study of tomato products, lycopene, and prostate cancer risk. J Natl Cancer Inst 94: 391-8.

9）青木雄大, 菅沼大行（2016）カロテノイド摂取にお ける野菜の加工・調理のすすめ. 日本食育学会誌 10, 163-70.

10) Gärtner C, Stahl W, Sies H (1997) Lycopene is more bioavailable from tomato paste than from fresh tomatoes. Am J Clin Nutr 66: 116-22.

11) Böhm V, Bitsch R (1999) Intestinal absorption of lycopene from different matrices and interactions to other carotenoids, the lipid status, and the antioxidant capacity of human plasma. Eur J Nutr 38: 118-25.

12) Parada J, Aguilera JM (2007) Food microstructure affects the bioavailability of several nutrients. J Food Sci 72: R21-32.

13) During A, Harrison EH (2004) Intestinal absorption and metabolism of carotenoids: insights from cell culture. Arch Biochem Biophys 430: 77-88.

14) Hussain MM, Pan $X$ (2015) Circadian regulation of macronutrient absorption. J Biol Rhythms 30: 459-69.

15) During A, Dawson HD, Harrison EH (2005) Carotenoid transport is decreased and expression of the lipid transporters SR-BI, NPC1L1, and ABCA1 is downregulated in Caco-2 cells treated with ezetimibe. J Nutr 135: 2305-12.

16) Moussa M, Landrier JF, Reboul E, Ghiringhelli O, Coméra C, Collet X, Fröhlich K, Böhm V, Borel P (2008) Lycopene absorption in human intestinal cells and in mice involves scavenger receptor class B type I but not Niemann-Pick C1-like 1. J Nutr 138: 1432-6.

17) Pan X, Hussain MM (2009) Clock is important for food and circadian regulation of macronutrient absorption in mice. J Lipid Res 50: 1800-13.
18) Hussain MM, Pan X (2012) Clock regulation of dietary lipid absorption. Curr Opin Clin Nutr Metab Care 15: $336-41$.

19) Hussain MM, Pan $X$ (2015) Circadian regulators of intestinal lipid absorption. J Lipid Res 56: 761-70.

20) Oshima S, Sakamoto H, Ishiguro Y, Terao J (1997) Accumulation and clearance of capsanthin in blood plasma after the ingestion of paprika juice in men. $J$ Nutr 127: 1475-9.

21) Aizawa K, Inakuma T (2007) Quantitation of carotenoids in commonly consumed vegetables in Japan. Food Sci Technol Res 13: 247-52.

22) Yoshida K, Yokoyama H, Oteki T, Matsumoto G, Aizawa K, Inakuma T (2011) Evaluation of the effect of dietary lycopene, the main carotenoid in tomato (Lycopersicon esculentum), on the in vivo renal reducing ability by a radiofrequency electron paramagnetic resonance method. J Agric Food Chem 59: 2966-71.

23) Kodama Y, Kishimoto Y, Muramatsu Y, Tatebe J, Yamamoto Y, Hirota N, Itoigawa Y, Atsuta R, Koike K, Sato T, Aizawa K, Takahashi K, Morita T, Homma S, Seyama K, Ishigami A (2015) Antioxidant nutrients in plasma of Japanese patients with chronic obstructive pulmonary disease (COPD), asthma-COPD overlap syndrome, and bronchial asthma. Clin Respir $J$ (in press).

24) Kanda Y (2012) Investigation of the freely available easy-to-use software 'EZR' for medical statistics. Bone Marrow Transplant 48: 452-8.

25) Mathews-Roth MM, Welankiwar S, Sehgal PK, Lausen NC, Russett M, Krinsky NI (1990) Distribution of [14C]canthaxanthin and [14C]lycopene in rats and monkeys. J Nutr 120: 1205-13.

26) Raghuvanshi S, Reed V, Blaner WS, Harrison EH (2015) Cellular localization of $\beta$-carotene $15,15^{\prime}$ oxygenase-1 (BCO1) and $\beta$-carotene $9^{\prime}, 10^{\prime}$ oxygenase- 2 (BCO2) in rat liver and intestine. Arch Biochem Biophys 15: 19-27.

27) Kiefer C, Hessel S, Lampert JM, Vogt K, Lederer MO, Breithaupt DE, Von Lintig J (2001) Identification and characterization of a mammalian enzyme catalyzing the asymmetric oxidative cleavage of provitamin. A J Biol Chem 276: 14110-6.

28) Zaripheh S, Boileau TW, Lila MA, Erdman JW Jr (2003) [14C]-lycopene and [14C]-labeled polar products are differentially distributed in tissues of F344 rats prefed lycopene. J Nutr 133: 4189-95.

29) Cohn W, Thürmann P, Tenter U, Aebischer C, Schierle J, Schalch W (2004) Comparative multiple dose plasma kinetics of lycopene administered in tomato juice, tomato soup or lycopene tablets. Eur J Nutr 43: 304-12.

30) Rock CL, Swendseid M, Jacob RA, Mckee RW (1992) Plasma carotenoid levels in human subjects fed a low carotenoid diet. J Nutr 122: 96-100.

31) Hara R, Wan K, Wakamatsu H, Aida R, Moriya T, Akiyama M, Shibata S (2001) Restricted feeding entrains liver clock without participation of the suprachias- 
matic nucleus. Gene Cells 26: 269-78.

32) Wakamatsu H, Yoshinobu Y, Aida R, Moriya T, Akiyama M, Shibata S (2001) Restricted-feeding-induced anticipatory activity rhythm is associated with a phase-shift of the expression of mPer1 and mPer2 mRNA in the cerebral cortex and hippocampus but not in the suprachismatic nucleus of mice. Eur J Neurosi 13 (6): 1190-6.
33）内田清久（1992）胆汁酸代謝と腸内細菌. ビフィズ 又 5, 157-172.

34）奥平典子, 荻原㻟男 (2006) 消化管トランスポーター を意識した医薬品開発 (1) 一 Influx transporter一. Drug Delivery System, 21, 134-41.

35）加藤隆一 (2014) 臨床薬物動態学, 第 4 版, p 27. 南江堂, 東京.

J Jpn Soc Nutr Food Sci 70: 147-155 (2017)

\title{
Original Paper
}

\section{Effect of Eating Time on Lycopene Bioavailability in Rats and Humans \\ Yudai Aoki, ${ }^{1}$ Kazutaka Yoshida, ${ }^{1}$ Yukihiro Nobuta, ${ }^{* 1}$ Satoshi Sunabori, ${ }^{1}$ Yuka Nishida, ${ }^{2}$ Hideo Kato, ${ }^{2}$ and Hiroyuki Suganuma ${ }^{1}$}

(Received January 5, 2017; Accepted April 3, 2017)

\begin{abstract}
Summary: Lycopene, a major carotenoid in tomato, is one of the strongest natural singlet-oxygen quenchers. Circadian rhythms have been suggested to affect the bioavailability of many nutrients, but no previous studies have investigated such effects on lycopene. Therefore, we investigated the effects of the timing of lycopene ingestion on its bioavailability in both rodents and humans. Rats or healthy human subjects consumed lycopenecontaining test food at different times, and their blood lycopene concentrations were then measured. It was found that the increase in blood lycopene level was highest when lycopene was ingested at the beginning of the active period (in rats) or in the morning (in humans). The result appeared to depend on not only the time slot chosen but also the length of the adjacent fasting period. Our findings suggest that the bioavailability of lycopene is maximal at breakfast because it follows a period of fasting.
\end{abstract}

Key words: lycopene, bioavailability, eating time, period of fasting

* Corresponding author (E-mail: Yukihiro_Nobuta@kagome.co.jp)

${ }^{1}$ Nature \& Wellness Research Department, Innovation Division, Kagome Co., Ltd., 17 Nishi-Tomiyama, NasuShiobara 329-2762, Japan

2 Department of Domestic Science, Tohoku Women's College, 1-1-16 Kiyohara, Hirosaki 036-8530, Japan Previous position; Department of Life Science, Prefectural University of Hiroshima, 1-1-71 Ujina-Higashi, Minami-ku, Hiroshima 734-8558, Japan 